\title{
СИСТЕМА ОРГАНІЗАЦІЙНИХ ЗАХОДІВ ЩОДО ПОЛІПШЕННЯ НАДАННЯ МЕДИЧНОЇ ДОПОМОГИ ПЕРШОМУ ПОКОЛІННЮ НАЩАДКІВ, ЯКІ НАРОДИЛИСЯ ВІД ПОСТРАЖДАЛИХ ВНАСЛІДОК АВАРІЇ НА ЧАЕС ТА ПРОЖИВАЮТЬ НА РАДІОАКТИВНО ЗАБРУДНЕНИХ ТЕРИТОРІЯХ
}

\author{
${ }^{1}$ ДУ «Національний науковий центр радіаційної медицини НАМН України», \\ м. Київ, Україна \\ ${ }^{2}$ Д3 «Український науково-практичний центр екстреної медичної допомоги та медицини катастроф \\ МОЗ України», м. Київ, Україна
}

\begin{abstract}
Мета: покращити систему надання медичної допомоги на первинній ланці поколінню нащадків постраждалих внаслідок аварії на ЧАЕС і які проживають на радіоактивно забруднених територіях.

Матеріали і методи. Загальна когорта становила 35893 нащадків першого покоління мешканців радіоактивно забруднених територій віком до 18 років, з них 18138 чоловічої та 17755 жіночої статей.

Залежно від часу народження нащадків поділено на чотири групи з урахуванням періодичності народження через кожних три роки з 1987 до 1999 рр. Період спостереження склав 1987-2016 рр., з народження до 18 років. Базою даних був державний реєстр України.

Результати. Виявлено 21390 випадків захворювань, з них хвороби органів дихання, органів травлення, хвороби ендокринної системи разом склали 66,87 \%.

Встановлено, що з досягненням 18-річчя тільки 37,3 \% нащадків загальної когорти були здоровими (перша група здоров'я), 29,88 \% - мали другу групу здоров'я (морфоорункціональні відхилення), 31,6 \% - третю групу здоров'я (хронічні захворюванння).

Запропоновано триетапну систему моніторингу стану здоров'я нащадків постраждалих внаслідок аварії на ЧАЕС віком від 3 до 18 років, які проживають на радіоактивно забруднених територіях, на первинній ланці. І етап масовий скринінг задекларованих пацієнтів для виявлення дітей та підлітків із ризиком розвитку захворювань. II етап - селективний скринінг для фрормування груп спостереження. III етап - медичне обстеження дітей та підлітків, віднесених до групи ризику, в амбулаторних умовах закладів спеціалізованої або високоспеціалізованої медичної допомоги постраждалим внаслідок аварії на ЧАЕС.
\end{abstract}

Висновки. Запропонована система дозволить забезпечити раннє виявлення дітей з групи ризику, які є нащадками постраждалих внаслідок аварії на ЧАЕС, з урахуванням специфіки захворювань та їх перебігу.

КЛЮЧОВІ СЛОВА: перше покоління нащадків; радіоактивно забруднені території; сімейний лікар.

Перше покоління нащадків (ППН), народжених у постійно проживаючих на радіоактивно забруднених територіях (РЗТ) родинах, є досить особливим за своїми клініко-епідеміологічними характеристиками контингентом. Вони народилися від опромінених батьків і впродовж свого життя піддаються опроміненню аварійними викидами Чорнобильської АЕС. Нащадки, опромінених внаслідок аварії на ЧАЕС батьків, мають високі показники захворюваності, інвалідності, ранню дитячу смертність [1-3, 5].

Фактично і потенційно якість здоров'я нащадків постраждалих гірша, ніж у їхніх однолітків за межами зон радіоактивного забруднення. Тому виникає потреба у наданні їм адекватної та ефективної медичної допомоги, особливо на рівні первинної ланки, де можливе перше виявлення прояву захворювань та морфофрункціональних (с) Ж. С. Ярошенко, С. О. Гур'єв, 2020 порушень в організмі. Особливого значення зазначена проблема набуває у період реформування охорони здоров'я. Ії̈ вирішення залежить від поєднання двох соціально-економічних фракторів, а саме виконання конституційних зобов'язань державою щодо забезпечення здоров'я осіб, які зазнали впливу іонізуючого опромінення внаслідок аварії на ЧАЕС, i, безпосередньо пов'язаних із проведенням медичної реформи, тобто змінами принципів фрінансування закладів охорони здоров'я, взаємодії медичних закладів та етапів рефрормування.

Мета роботи: покращити систему надання медичної допомоги на первинній ланці першому поколінню нащадків, які народилися від постраждалих внаслідок аварії на ЧАЕС і проживають на радіоактивно забруднених територіях, на основі отриманих нами результатів проведених клінікоепідеміологічних досліджень. 
Матеріали і методи. Загальна когорта ППН віком до 18 років мешканців РЗТ становила 35893 особи, з них 18138 нащадків чоловічої (НЧС) та 17755 жіночої статей (НЖС) з індивідуальними дозами іонізуючого опромінення 3 10 районів чотирьох областей України, а саме: Київської (Іванківський), Житомирської (Народицький, Овруцький, Олевський, Коростенський), Рівненської (Рокитнівський, Дубровицький, Сарненський), Чернігівської (Ріпкинський, Козелецький). Залежно від часу народження нащадків поділено на чотири групи з урахуванням періодичності народження через кожних три роки 3 1987 до 1999 рр. Період спостереження тривав упродовж 1987-2016 рр., з народження до досягнення 18-річчя. Стан здоров'я нащадків оцінювали за даними державного реєстру України.

Результати дослідження та їх обговорення. Аналіз діючих нормативних актів та практична реалізація концепції лікаря загальної практики вказує на недостатню ефективність надання медичної допомоги ППН внаслідок:

- необізнаності сімейних лікарів особливостей розвитку патологій, що не дозволяє своєчасно виявити та надати адекватну медичну допомогу;

- обмеженості доступу до певних методів обстеження та консультацій вузькопрофрільних спеціалістів;

- недостатньої потужності більшості закладів первинної медико-санітарної допомоги (ПМСД) для проведення поглиблених медичних оглядів дітей та підлітків.

Тому, враховуючи наявність досить розвинутої системи надання спеціалізованої медичної допомоги постраждалим внаслідок аварії на ЧАЕС, варто покласти фрунціонал надання медичної допомоги 3 метою проведення довгострокового моніторингу лікарями сімейної практики на спеціалістів спеціалізованих центрів радіаційного захисту населення.

За проведеними клініко-епідеміологічними дослідженнями встановлено, що в структурі вперше виявлених непухлинних захворювань ППН домінують хвороби органів дихання, ендокринної системи, хвороби органів травлення, які разом становлять 66,87 \% (табл. 1).

Значну частку склали хвороби системи кровообігу, кістково-м'язової системи та сполучної тканини, хвороби нервової системи, симптомів, ознак та відхилень від норми (разом 23,81 \%). Структура захворювань нащадків за гендерною ознакою ідентична структурі загальної когорти.

За весь період спостереження (після досягнення нащадками 18-річчя) спостерігали втрату здоров'я ППН. У ранньому віці відсоток здорових дітей серед нащадків склав 86,4, а 3 досягненням 18-річчя тільки 37,3 \%, а третина нащадків $(29,88$ \%) загальної когорти мала другу групу здоров'я (наявність морфофрункціональних відхилень). Також встановлено, що питома вага нащадків із хронічними захворюваннями (третя група здоров'я) збільшилася з 5,08 \% в ранньому дитинстві до 31,6 \% з досягненням 18 років. Суттєве погіршення їхнього стану здоров'я, а саме збільшення ППН із хронічними захворюваннями відбувалося у віці 5-7 років (25,34-27,76 \%) та 15-18 років (27,34-31,6 \%).

Зважаючи на вказані особливості та враховуючи переважання в питомій вазі захворюваності вищезазначеними непухлинними хворобами, розроблено систему моніторингу стану здоров'я першого покоління нащадків, які народилися від постраждалих внаслідок аварії на ЧАЕС, для профрілактики захворювань та збереження їхнього здоров'я.

Таблиця 1. Поділ уперше виявленої непухлинної захворюваності першого покоління нащадків загальної когорти після досягнення ними 18-річчя за гендерною ознакою, \%

\begin{tabular}{|l|c|c|c|c|c|c|}
\hline \multicolumn{1}{c|}{ Класи непухлинних хвороб } & \multicolumn{2}{c|}{ Разом } & \multicolumn{2}{c|}{ HЧС } & \multicolumn{2}{c|}{ HЖС } \\
\cline { 2 - 7 } за МКХ-10 & абс. & $\%$ & абс. & $\%$ & абс. & \% \\
\hline Усі хвороби & 21390 & 100,00 & 10697 & 50,01 & 10693 & 49,99 \\
\hline Хвороби органів дихання & 7845 & 36,68 & 4146 & 38,76 & 3699 & 34,59 \\
\hline Хвороби ендокринної системи & 3297 & 15,41 & 1550 & 14,49 & 1747 & 16,34 \\
\hline Хвороби органів травлення & 3190 & 14,91 & 1517 & 14,18 & 1673 & 15,65 \\
\hline Хвороби системи кровообігу & 1759 & 8,22 & 886 & 8,28 & 873 & 8,16 \\
\hline Хвороби кістково-м'язової системи & 1471 & 6,88 & 752 & 7,03 & 719 & 6,72 \\
\hline Хвороби нервової системи & 896 & 4,19 & 385 & 3,60 & 511 & 4,78 \\
\hline Симптоми, ознаки та відхилення від норми & 833 & 3,89 & 446 & 4,17 & 387 & 3,62 \\
\hline Хвороби крові та кровотворних органів & 570 & 2,66 & 257 & 2,40 & 313 & 2,93 \\
\hline Хвороби ока та придаткового апарату & 508 & 2,37 & 240 & 2,24 & 268 & 2,51 \\
\hline Хвороби сечостатевої системи & 429 & 2,01 & 193 & 1,80 & 236 & 2,21 \\
\hline Хвороби шкіри та підшкірної клітковини & 210 & 0,98 & 114 & 1,07 & 96 & 0,90 \\
\hline Хвороби вуха та соскоподібного відростка & 147 & 0,69 & 70 & 0,65 & 77 & 0,72 \\
\hline Вроджені аномалії розвитку & 133 & 0,62 & 83 & 0,78 & 50 & 0,47 \\
\hline Розлади психіки та поведінки & 102 & 0,48 & 58 & 0,54 & 44 & 0,41 \\
\hline
\end{tabular}


Враховуючи, що народжені від опромінених батьків нащадки несуть не тільки тяжкість спадковості, а й, проживаючи на РЗТ, перебувають в зоні йодної ендемії та піддаються впливу несприятливих фракторів навколишнього середовища (хронічне опромінення, хімічні забруднення), з метою підвищення ефрективності проведення організаційних та лікувально-профілактичних заходів, спрямованих на запобігання захворюваності та інвалідності дітей та підлітків, запропоновано триетапну систему моніторингу стану здоров'я дітей на первинній ланці від 3 до 18 років життя.

Етапність включає:

І етап - проведення масового скринінгу (100\% охоплення задекларованих пацієнтів) для виявлення дітей та підлітків із фракторами ризику розвитку захворювань органів дихання, травлення та ендокринної системи.

II етап - проведення селективного скринінгу для фрормування груп спостереження дітей та підлітків із підозрою на наявність захворювань ендокринної системи, бронхолегеневої системи, патології органів травлення для встановлення заключного або попереднього діагнозу.

III етап - медичне обстеження дітей та підлітків, віднесених до групи ризику, в амбулаторних умовах закладів спеціалізованої медичної допомоги постраждалим внаслідок аварії на ЧАЕС або в Державній установі «Національний науковий центр радіаційної медицини НАМН України» (ННЦРМ) для верифрікації діагнозу, виявлення супутніх захворювань, надання рекомендацій і проведення відповідного, в разі потреби, лікування.

Використання скринінг-тестів як інструменту раннього виявлення дітей та підлітків, які проживають на РЗТ, із фракторами ризику розвитку захворювань визначеними у нашому дослідженні (симптоматики) дозволяє лікарю ПМСД сорормувати первинну інформаційну базу даних дітей 3 наявністю очікуваних відхилень в стані здоров'я.

На І етапі, в умовах ПМСД, фрормується первинна інформаційна база даних дітей групи спостереження 3 факторами ризику на основі анкетування методом масового скринінг-тесту. Анкета включає підготовлений з урахуванням визначеної в цій науково-дослідній роботі найбільшої захворюваності нащадків адаптований тестопитувальник, а саме хвороб органів дихання, травлення та ендокринної патології.

За результатами оцінки масової скринінг-анкети, лікар ПМСД фрормує групу дітей з фракторами ризику розвитку хвороб органів дихання, травлення та ендокринної системи.

На II етапі, серед дітей з ризиком розвитку вищезазначених захворювань, проводять селективний скринінг, який включає додаткове анкетування батьків дітей 3 урахуванням їхнього генеалогічного анамнезу та інфрормації про спосіб життя та звички, як опосередкованих фракторів негативного впливу на формування здоров'я дітей та підлітків, та питання щодо психоемоційного стану дітей. Цей етап скринінгу включає також обстеження дітей з групи фракторів ризику в лікаря ПМСД та радіологічний контроль внутрішнього опромінення за допомогою лічильника випромінювання людини.

При виявленні у дитини відхилень від норми, за результатами обстеження у лікаря ПМСД, 3 урахуванням анамнезу хвороб, скарг, невідповідності біологічного віку календарному контролю, результатів загального аналізу крові та сечі, даних ЕКГ-дослідження, перевищення контрольних рівнів іонізуючого випромінювання (0,5 мЗв/рік), визначення негативних факторів впливу, за результатами анкетування батьків, лікар обов'язково направляє дітей на дообстеження у заклади спеціалізованої або високоспеціалізованої медичної допомоги постраждалим внаслідок аварії на ЧАЕС. Лікар ПМСД при цьому формує базу даних дітей, яким потрібно проводити поглиблене медичне обстеження у закладах вищого рівня.

Анкети масового та селективного скринінгу в форматі Excel фрормуються щорічно, починаючи 3 трьох років від народження, надсилаються на електронну адресу батьків лікарем ПМСД, з яким підписана декларація, що дозволяє батькам заповнити її не відвідуючи лікаря (обов'язково зі зворотним зв'язком). Базою підготовленої нами анкети слугували методичні рекомендації, розроблені групою науковців $Є$. Степановою і співавт. [6], та публікації К. Бруслової [4].

Ha III етапі - для уточнення діагнозу дітям проводять додаткові інструментальні та лабораторні обстеження з урахуванням захворювань органів дихання, травлення та ендокринної системи. У їх числі:

- дослідження фрункції зовнішнього дихання (спірографрія) всім дітям після досягнення 6-річного віку один раз на 2 роки (зважаючи на розвиток комплексної патології сполучної тканини в анатомічній ділянці грудної клітки), а дітям, які мають алергічну реакцію (у тому числі спадкову підозру), після перенесених в анамнезі захворювань (пневмонії, бронхіоліту, обструктивного бронхіту) - один раз на рік;

- консультація у дитячого стоматолога для скринінгу здоров'я зубів та виявлення можливих аномалій розвитку зубощелепної системи, а починаючи з 6 років із навчанням гігієни ротової порожнини з метою профрілактики розвитку карієсу та УЗД органів черевної порожнини один раз на рік; копрограму (як маркер процесів травлення в харчовому ланцюжку);

- УЗД щитоподібної залози, контроль тиреотропного гормону та цукру в крові. 
Педіатр-експерт спеціалізованої поліклініки за результатами проведених лабораторних та інструментальних досліджень верифікує діагнози й формує базу даних дітей, які потребують довгострокового моніторингу. За необхідності, залучає вузькопрофрільних спеціалістів для уточнення рекомендацій та (або) направляє на стаціонарне лікування.

Зважаючи на значну питому вагу патології опорно-рухового апарату, необхідно також проводити обстеження дитячим ортопедом-травматологом для здійснення коригуючих заходів дітей до 5 років 2 рази на рік, 35 до 10 років - один раз на рік, з 10 до 15 років - 2 рази на рік, 316 до 18 років - один раз на рік. Така схема ортопедичних оглядів зумовлена особливостями розвитку опорно-рухового апарату в препубертатний та пубертатний періоди.

Довгостроковий моніторинг пацієнтів із хронічними захворюваннями проводять у спеціалізованому та високоспеціалізованому закладі до досягнення стійкої ремісії захворювань з подальшим дистанційним супроводом вузькопрофільними спеціалістами сімейних лікарів.

Пропонуємо також клінічний маршрут пацієнта з урахуванням схеми функціонування та взаємодії лікарів ПМСД та закладів спеціалізованої медичної допомоги постраждалим внаслідок аварії на ЧАЕС (ННЦРМ).

Він включає:

• запрошення до лікаря ПМСД (сімейний лікар, педіатр);

- направлення до закладів спеціалізованої або високоспеціалізованої медичної допомоги постраждалим внаслідок аварії на ЧАЕС;

- реєстрацію у закладі спеціалізованої або високоспеціалізованої медичної допомоги постраждалим внаслідок аварії на ЧАЕС;

- проведення лабораторно-діагностичних досліджень, оформлення заключення педіатраексперта;

- залучення вузькопрофрільних спеціалістів (за необхідності).

Розроблено та запропоновано триетапну систему моніторингу стану здоров'я першого покоління нащадків, які народилися від опромінених батьків, які проживають на РЗТ, дає можливість у повному обсязі лікарю ПМСД охопити медичним контролем пацієнтів, з якими укладені декларації.

Використання скринінг-тестів як інструменту раннього виявлення та профрілактики захворювань серед проживаючих на РЗТ дозволяє з мінімальними фонансовими витратами виділяти групи ризику серед дітей та підлітків для своєчасного прийняття управлінських рішень, зменшення вірогідності виникнення ускладнень, збереження та відновлення здоров'я нащадків опромінених батьків.
Своєчасне виявлення порушень стану здоров'я дітей дозволяє запобігти розвитку ускладнень, що призводять до інвалідизації та ранньої смертності. Селективний скринінг дітей з підозрою на наявність патології дає можливість виокремити дітей, яким необхідне поглиблене обстеження на вищих рівнях медичної допомоги, що зменшує залучення вузькопрофрільних спеціалістів.

Дана система забезпечує зворотний зв'язок між лікарем сімейної практики та спеціалістами високоспеціалізованої допомоги, що сприяє повноцінному та адекватному призначенню лікування на первинній ланці за встановленим діагнозом, проведенню профрілактики загострень та реабілітації пацієнтів.

Узагальнено запропонована система представлена в наведеній нижче схемі (табл. 2).

Пропонована схема фрункціонування та взаємодії лікарів ПМСД та закладів спеціалізованої та високоспеціалізованої медичної допомоги постраждалим внаслідок аварії на ЧАЕС дозволяє:

- проводити чіткий відбір та направляти за клінічним маршрутом дітей у разі необхідності;

- дає можливість отримати нащадкам постраждалих спеціалізованої та високоспеціалізованої медичної допомоги;

- концентрувати фрінансові ресурси для надання медичної допомоги першому поколінню нащадків без перевантаження фрінансових витрат закладів ПмСд;

- фрінансувати та організовувати медичну допомогу в межах державних програм;

- концентрувати інорормаційні дані для розробки, та, у разі необхідності, коригувати лікувально-діагностичні та лікувально-профрілактичні заходи для проведення динамічних наукових досліджень.

Зважаючи на особливості контингенту ППН та певну розпорошеність їх за ознакою місця проживання з метою забезпечення гарантованого Конституцією права на медичну допомогу постраждалим внаслідок аварії на ЧАЕС, ми вважаємо за доцільне залучення фрахівців вторинної та третинної ланки (вузькопрофрільних спеціалістів) як фрактично фрункціональну первинну ланку надання медичної допомоги за рахунок державних програм, що дозволить досягти балансу кластерів завдань, a, з іншого боку, - доповнює функцію диспансерів на сучасному етапі фрінансування.

У ході реформування охорони здоров'я бажано звернути увагу на поліпшення підготовки фрахівців, а саме, при проходженні інтернатури молодими спеціалістами, які планують працювати на РЗТ, підвищення теоретичних знань, проведення семінарів і створення тематичних циклів удосконалення фрахівців на післядипломному етапі навчання з урахуванням особливостей системи моніторингу здоров'я нащадків постраждалих, які 
Таблиця 2. Схема функціонування та взаємодії лікарів ПмСД та закладів спеціалізованої медичної допомоги постраждалим внаслідок аварії на ЧАЕС (ННЦРМ)

\begin{tabular}{|c|c|c|c|c|c|}
\hline Етап & Захід & Метод & Виконавець & Взаємодія & Результат \\
\hline 1 & $\begin{array}{l}\text { Масовий } \\
\text { скринінг }\end{array}$ & Анкетування & Лікар ПМСД & Батьки & Інфрормаційна база \\
\hline \multirow[t]{2}{*}{ II } & \multirow{2}{*}{$\begin{array}{l}\text { Селективний } \\
\text { скринінг }\end{array}$} & Анкетування & \multirow[t]{2}{*}{ Лікар ПМСД } & Батьки & \multirow{2}{*}{$\begin{array}{l}\text { Інформаційний } \\
\text { реєстр даних клініко- } \\
\text { лабораторних } \\
\text { досліджень груп } \\
\text { ризику }\end{array}$} \\
\hline & & $\begin{array}{l}\text { Лабораторно-клінічне } \\
\text { обстеження }\end{array}$ & & $\begin{array}{l}\text { Лікар закладу } \\
\text { спеціалізованої } \\
\text { допомоги (ННЦРМ) }\end{array}$ & \\
\hline III & $\begin{array}{l}\text { Медичне } \\
\text { обстеження }\end{array}$ & $\begin{array}{l}\text { Спеціалізоване } \\
\text { (високоспеціалізоване) } \\
\text { лабораторно-клінічне } \\
\text { обстеження }\end{array}$ & $\begin{array}{l}\text { Лікар закладу } \\
\text { спеціалізованої } \\
\text { допомоги (ННЦРМ) }\end{array}$ & Лікар ПМСД & $\begin{array}{l}\text { Клініко-епідеміологіч- } \\
\text { ний реєстр }\end{array}$ \\
\hline
\end{tabular}

проживають на РЗТ, із забезпеченням державного фрінансування.

У загальнодержавних заходах соціально-економічного та медичного захисту постраждалих внаслідок аварії на ЧАЕС бажано посилення заходів, які спрямовані на:

- фрормування здорового способу життя у всіх дітей, які проживають на Р3Т;

- поліпшення харчування в освітніх закладах;

- фрормування культури здорового способу життя у дітей в освітницьких закладах (заняття з фрізкультури мають стати «модними», з цікавим наповненням та рухливими іграми);

• креативне донесення інфрормації щодо основних правил гігієни.

Такий пропонований нами комплексний підхід, який складається з трьох етапів, дозволить:

- своєчасно виявляти захворювання у нащадків постраждалих та направляти дітей, за потреби, на вищі рівні надання спеціалізованої медичної допомоги;

- підвищувати якість надання медичної допомоги за рахунок покращення підготовки медичних працівників;

- проводити дієву профілактику виникнення та розвитку захворювань у дітей, які проживають на P3T;

• контролювати розвиток патології в популяції та обґрунтовувати пропозиції щодо покращення надання первинної медичної допомоги на первинній ланці.

Загалом запропонована нами система допоможе знайти вкрай необхідний баланс між вимогами медичної рефрорми та конституційним обов'язком держави в збереженні здоров'я покоління дітей, які народжуються від опромінених батьків і проживають на РЗТ.
Зважаючи на фріксоване фрінансування одного пацієнта з урахуванням капітаційної ставки, яке передбачене підписанням декларації у сімейного лікаря, що ніяким чином не покриває витрат на проведення діагностичних процедур, необхідним $€$, як довів досвід інших країн, створення спеціальних державних програм для моніторингу стану здоров'я нащадків постраждалих.

\section{Висновки}

1. Запропонована система дозволить забезпечити раннє виявлення дітей з групи ризику, які $є$ нащадками постраждалих внаслідок аварії на ЧAEC, з урахуванням специоріки захворювань та їх перебігу.

2. Триетапна система моніторингу забезпечує взаємодію лікарів первинної ланки з фахівцями високоспеціалізованих закладів медичної допомоги за принципами зворотного зв'язку, що сприятиме довгостроковій ремісії захворювань і одужанню дітей та, що не менш важливо, залученню батьків до фрормування здорового способу життя у сім'ї та підтримки здоров'я дитини.

3. Для забезпечення надання ефективної медичної допомоги нащадкам постраждалих внаслідок аварії на ЧАЕС необхідно удосконалювати підготовку сімейних лікарів із питань медико-гігієнічних наслідків Чорнобильської катастрофи.

Перспективи подальших досліджень полягають у продовженні розробок скринінг-тестів раннього виявлення дітей з групи ризику на первинній ланці, які є нащадками постраждалих внаслідок аварії на ЧАЕС, з урахуванням захворювань системи кровообігу, системних захворювань сполучної тканини, крові та кровотворних органів, розладів психіки та поведінки, з подальшою імплементацією їх у заклади ПМСД за умов реформування на основі законодавчих актів.

\section{Список літератури}

1. Бебешко В. Г. Радіо-біофізичні та медико-гігієнічні наслідки Чорнобильської катастрофри: шляхи пізнання та подолання : практичний посібник сімейного лікаря / В. Г. Бебешко, Б. С. Прістер, М. І. Омельянець. - Ужгород, 2017. - 504 c. 
2. Власюк Н. В. Самооцінка здоров'я населення України внаслідок Чорнобильської катастрофи у пізній фразі аварії / Н. В. Власюк, О. Є. Тарасюк, М. Ю. Антомонов // Environment \& Health. - 2016. - № 4. - C. 41-45.

3. Гунько Н. В. Демографрічні наслідки Чорнобильської катастрофи в Україні. Тридцять років Чорнобильської катастрофи: радіологічні та медичні наслідки : Національна доповідь України [Електронний ресурс] / Н. В. Гунько ; за ред. Д. А. Базики. - К., 2016. - Режим доступу : https://nrcrm.gov.ua/publications/monographs/ (дата звернення: 26.09.2018).

4. Прогноз перебігу гострих лімсобластних лейкемій Чорнобильського походження у дітей України залежно від причин перерв при проведенні стандартної хіміотерапії [Електронний ресурс] / В. Г. Бебешко, К. М. Бруслова, Н. М. Цвєткова та ін. // Проблеми радіаційної медицини та радіобіології. - 2019. - Вип. 24. - Режим доступу : httр:// www.radiationproblems.org.ua/24_2019_ua_s322.html (дата звернення: 01.06.2020).

5. Степанова Є. І. Медичні наслідки Чорнобильської катастрофри у дітей, які зазнали дії іонізуючого опромінення, та дітей, які народилися від опромінених батьків. Тридцять років Чорнобильської катастрофи: радіологічні та медичні наслідки : Національна доповідь України [Електронний ресурс] / Є. І. Степанова ; за ред. Д. А. Базики. - К., 2016. Режим доступу : http://dazv.gov.ua/images/pdf/national_dopovid_2016.pdf (дата звернення: 15.10.2018).

6. Степанова Е. И. Оптимизация формирования групп риска среди детей, испытавших радиационное воздействие : методические рекомендации / Е. И. Степанова, И. Е. Колпаков. - К., 1996.

\section{References}

1. Bebeshko, V.H., Prister, M.I., \& Omelyahez, M.I. (2018). Radio-biofizychni ta medyko-hihiienichni naslidky Chornobylskoi katastrofy: shliakhy piznannia ta podolannia: praktychnyi posibnyk simeinoho likaria [Radio-biophysical and health and hygiene consequences of Chornobyl catastrophe: ways of knowledge and overcoming]. Uzhhorod [in Ukrainian].

2. Vlasyuk, N.V., Tarasyuk, O.Ye., \& Antomonov, M.Yu. (2016). Samootsinka zdorovia naselennia Ukrainy vnaslidok Chornobylskoi katastrofy u piznii fazi avarii [Health self-assessment of Ukrainian population as a result of Chornobyl accident on the late phase]. Environment \& Health, 4, 41-45 [in Ukrainian].

3. Hunko, N., Dubova, N., Khomenko, I., Korotkova, N, Omelianets, M., \& Piven, N. (2016). Demohrafichni naslidky Chornobylskoi katastrofy $v$ Ukraini. Trudtsziat rokiv Chornobylskoi katastrofy: radiobolohichni ta medychni naslidky: Natsionalna dopovid Ykrainy [Health consequences of Chornobyl disaster in children exposed to ionizing radiation and children born to exposed parents]. Bazykyi, D.A. (Ed.). Kyiv. Retrieved from: https://nrcrm.gov.ua/downloads/2017/ monograph_last.pdf [in Ukrainian].

4. Bebeshko, V.G, Bruslova, K.M., Tsvetkova, N.M., Lyashenko, L.O., Pushkariova, T.I., Honchar, L.O., Trykhlib, I.V., Yatsemirskyi, S.M., Samson, Yu.M., Boyarskyi, V.H., Hryshchenko, K.V., Polyanska, V.M., \& Dmytrenko, I.V. (2019). Prohnoz perebihu hostrykh limfoblastnykh leikemii Chornobylskoho pokhodzhennia u ditei Ukrainy zalezhno vid prychyn pererv pry provedenni standartnoi khimioterapii [Prognosis of the course of chornobyl/originated acute lymphoblastic leukemia in children in ukraine depending on the reason of standard chemotherapy interruption]. Problemy radiatsiinoi medytsyny ta radiobolohii - Problems of Radiation Medicine and Radiobiology, 24, 335-350. Retrieved from: http://www. radiationproblems.org.ua/24_2019_ua_s322.html [in Ukrainian].

5. Stepanova, Ye.I. (2016). Medychni naslidky Chornobylskoyi katastrofy u ditei, yaki zaznaly dii ionizuiuchoho oprominennia, ta ditei, iaki narodylysia vid oprominenykh batkiv. Trydtsiat rokiv Chornobylskoi katastrofy: radiobolohichni ta medychni naslidky: Natsionalna dopovid Ukrainy [Health consequences of Chornobyl disaster in children exposed to ionizing radiation and children born to exposed parents]. Bazyka, D.A. (Ed.). Kyiv. Retrieved from: http://dazv.gov.ua/ images/pdf/national_dopovid_2016.pdf [in Ukrainian].

6. Stepanova, E.I., \& Kolpakov, I.Ye. (1986). Optymizatsziya formirovaniya grupp riska sredi detey, ispytavshikh radiatsionnoe vozdeystvie: Metodicheskie rekomendatsii. [Optimization of the formation of risk groups among children who have experienced radiation exposure: Methodological recommendations]. Kyiv [in Russian].

\section{THE SYSTEM OF ORGANIZATIONAL MEASURES SEEKING TO IMPROVE MEDICAL CARE TO THE FIRST-GENERATION OFFSPRING BORN TO THOSE AFFECTED BY THE CHORNOBYL ACCIDENT AND LIVING IN THE RADIOACTIVELY CONTAMINATED AREAS \\ Zh. S. Yaroshenko ${ }^{1}$, S. O. Huryev ${ }^{2}$}

${ }^{1}$ National Research Centre for Radiation Medicine of the National Academy of Medical Sciences of Ukraine, Kyiv, Ukraine

${ }^{2}$ Ukrainian Scientific and Practical Centre for Emergency Medical Care and Disaster Medicine, Kyiv, Ukraine

Purpose: to improve the primary medical care system provided to the generation of offspring born to those affected by the Chornobyl accident and living in radioactively contaminated areas.

Materials and Methods. The total cohort was 35 893, including 18138 male and 17755 female offspring. Subject to the time of birth, the offspring were divided into four groups, taking into account the frequency of birth every three years from 1987 to 1999. The observation period was conducted during 1987-2016. The database was the state register of Ukraine.

Result. There were detected 21390 cases of diseases among the first-generation offspring whereby diseases of the respiratory system, digestive organs, diseases of the endocrine system jointly amounted to $66.87 \%$.

It was found that by the age of 18 , only $37.3 \%$ of the general cohort offspring were healthy (first group of health), $29.88 \%$ - had a second group of health (with morpho-functional abnormalities), $31.6 \%$ - had a third group of health (with chronic diseases). 
At the primary medical care, there was proposed a three-stage system for monitoring the health of the offspring of those affected by the Chornobyl accident aged 3 to 18 and living in radioactively contaminated areas.

Stage I is mass screening of patients registered by a family doctor and is used to identify children and adolescents at risk of developing the disease. Stage II is selective screening for the formation of observation groups. Stage III is a medical examination of children and adolescents registered with the risk group in outpatient setting of the facilities of specialized or highly specialized medical care to those affected by the Chornobyl accident.

Conclusions. The proposed system would enable to early detect children from the risk group who are offspring of those affected by the Chornobyl accident, subject to the specifics of diseases and their course.

KEY WORDS: first-generation offspring; radioactively contaminated areas; family doctor.

Рукопис надійшов до редакції 29.05.2020 p.

\section{Відомості про авторів:}

Ярошенко Жанна Степанівна - ДУ «Національний науковий центр радіаційної медицини НАМН України», головний лікар клініки; тел.: +38(044) 450-81-92.

Гур'єв Сергій Омелянович - ДЗ «Український науково-практичний центр екстреної медичної допомоги та медицини катастроф МОЗ України», заступник директора; тел.: +38(044) 518-57-08. 